\title{
Populus primaveralepensis sp. nov. (Salicaceae, Malpighiales), a new species of white poplar from the Bosque La Primavera Biosphere Reserve in western Mexico
} \author{
Gerardo HERNÁNDEZ-VERA ${ }^{6}$ \& Osvaldo ZUNO DELGADILLO ${ }^{7}$ \\ Botánica, Dpto. de Botánica y Zoología, Univ. de Guadalajara, c. ${ }^{\circ}$ Ramón Padilla 2100, \\ Las Agujas, La Venta del Astillero, C. P. 45221, Zapopan, Jalisco, Mexico. \\ ${ }^{7}$ Bosque la Primavera, Av. Vallarta no. 6503 Local E-38, Ciudad Granja, C. P. 45010, \\ Zapopan, Jalisco, Mexico.

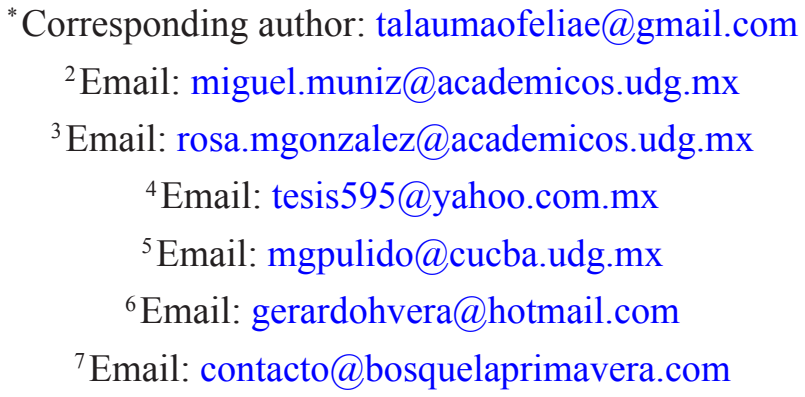

J. Antonio VÁZQUEZ-GARCÍA ${ }^{1, *}$, Miguel Ángel MUÑIZ-CASTRO², Rosa Elena MARTÍNEZGONZÁLEZ ${ }^{3}$, Gregorio NIEVES-HERNÁNDEZ ${ }^{4}$, María Guadalupe PULIDO-ÁVILA ${ }^{5}$,

1,2,3,4,5,6 Herbario IBUG (“Luz María Villarreal de Puga”), Laboratorio de Ecosistemática, Inst. de

\begin{abstract}
Populus primaveralepensis A.Vázquez, Muñiz-Castro \& Zuno sp. nov., a new species from relict gallery cloud forest in Bosque La Primavera Biosphere Reserve (Mexico), is described and illustrated. The new species belongs to $P$. subsect. Tomentosae Hart., and is morphologically similar to P. luziarum A.Vázquez, Muñiz-Castro \& Padilla-Lepe, but differs from it in having taller trees without root suckers, white and ringed young stems and branches, a branching angle of ca $45^{\circ}$, leaves with higher blade to petiole ratio, leafs frequently elliptic or ovate to widely ovate (vs widely ovate to ovatedeltoid), denser inflorescences, and shorter capsules. The conservation status of the species was assessed as Critically Endangered (CR).
\end{abstract}

Keywords. Mexico, Populus luziarum, Populus simaroa, Populus sect. Aigeiros, Salicaceae.

Vázquez-García J.A., Muñiz-Castro M.Á., Martínez-González R.E., Nieves-Hernández G., Pulido-Ávila M.G., Hernández-Vera G. \& Zuno Delgadillo O. 2019. Populus primaveralepensis sp. nov. (Salicaceae, Malpighiales), a new species of white poplar from the Bosque La Primavera Biosphere Reserve in western Mexico. European Journal of Taxonomy 498: 1-16. https://doi.org/10.5852/ejt.2019.498 


\section{Introduction}

The genus Populus L. (Salicaceae Mirb., Malpighiales Juss. ex Bercht. \& J.Presl) consists of 30 species (aspens, cottonwoods, and poplars) of fast growing and deciduous trees and shrubs, with a boreal to subtropical distribution, and with a great ecological and economical importance (Eckenwalder 1996; Vázquez-García et al. 2017). In Mexico, the genus currently comprises ten species, belonging to four sections: P. sect. Abaso Eckenw., P. sect. Aigeiros Duby, P. sect. Populus, and P. sect. Tacamahaca Spach (Eckenwalder 1977a, 1977b; Rzedowski 1985; Vázquez-García \& Cuevas-Guzmán 1989; MartínezGonzález \& González-Villarreal 2002, 2005; Vázquez-García et al. 2017). Five species are reported from western and southern Mexico, one belonging to P. sect. Aigeiros: P. fremontii subsp. mesetae Eckenw., from northern Jalisco and the region Los Altos (Eckenwalder 1977a, 1977b; Martínez-González \& González-Villarreal 2002), and four of them belonging to P. sect. Populus: P. guzmanantlensis A.Vázquez \& Cuevas ( $P$. subsect. Tomentosae Hart.), endemic to the Jaliscan region of the Sierra Madre del Sur (Vázquez-García \& Cuevas-Guzmán 1989), P. luziarum A.Vázquez, Muñiz-Castro \& PadillaLepe, endemic to the municipality of Zapopan, Jalisco (Vázquez-García et al. 2017), P. simaroa Rzed. from the State of Mexico, Guerrero, and Michoacán (Rzedowski 1975), and P. tremuloides Michx. ( $P$. subsect. Trepidae (Dode) Tamm) recorded from the municipality of Mezquitic, Jalisco (Michaux 1803; Martínez-González \& González-Villarreal 2002).

Here, we describe and illustrate a new species of $P$. (sect. Populus) subsect. Tomentosae, P. primaveralepensis A.Vázquez, Muñiz-Castro \& Zuno sp. nov. growing in relict cloud forest at the Bosque La Primavera Biosphere Reserve (BLPBR) in Jalisco, Mexico.

\section{Material and methods}

Populus primaveralepensis sp. nov. was first collected at the BLPBR in 2009 from a single small tree, and the specimen was kept at IBUG (Harker et al. 4045 leg.). However, it remained cryptic since it was determined and filed in the IBUG herbarium as P. simaroa Rzed. Recently, in February 2013, J. PadillaLepe, a member of a seed-collecting team at the BLPBR, led by O. Zuno-Delgadillo, found it again, but this time as the dominant canopy tree in the relict gallery cloud forest of the eastern Tala, Jalisco. The biologist J. Padilla-Lepe only collected a single sterile terminal twig, because he thought it was a second locality of $P$. luziarum, a recently described species that he had found a year earlier in western Tesistán, in Zapopan, Jalisco (Vázquez-García et al. 2017). A month later (March 2013), A. Vázquez, J. PadillaLepe, and O. Zuno-Delgadillo revisited the population for a closer examination, unveiling substantial qualitative and quantitative differences from the latter in the habit (non-soboliferous and taller trees with whitish branches), narrower leaves, and denser male and female inflorescences (Table 1), allowing us to conclude that we were dealing with an undescribed species of $P$. (sect. Populus) subsect. Tomentosae.

The morphological description and the illustrations are based on fresh and herbarium material. Leaf description and terminology of reproductive structures follow Radford et al. (1974), Eckenwalder (2010), and Dickmann \& Kuzovkina (2014). The herbarium acronyms follow Thiers (2017). Detailed examination of herbaria type specimens and electronic images of type material for both $P$. guzmanantlensis (holotype: ZEA; isotypes: BRIT, CAS, CHAPA, CIIDIR, ENCB, F, GH, LE, MEXU, MICH; MO, TEX, UAMIZ, WIS) and P. simaroa (holotype: ENCB; isotypes: CAS, ENCB, G, MEXU, MICH, MO, NY, OS, P, US), available at the Global Plant JSTOR website (except for the holotype of $P$. guzmanantlensis), allowed us to determine the morphological differences among the taxa (Table 1). For the accepted names we followed POWO (2018). Authors and names of plants follow the IPNI (2018). The conservation status was assessed based on the criteria of IUCN (2012). 


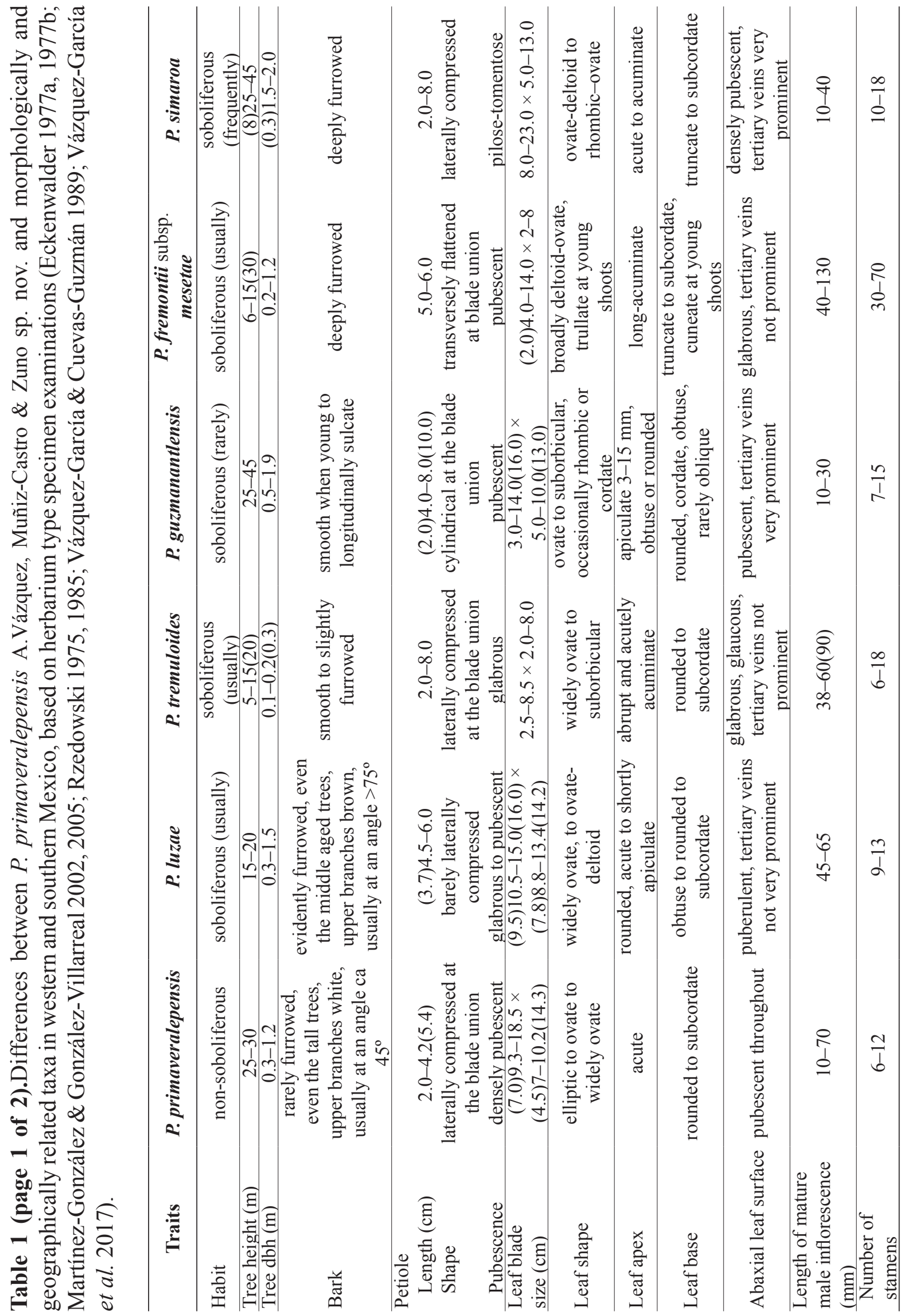




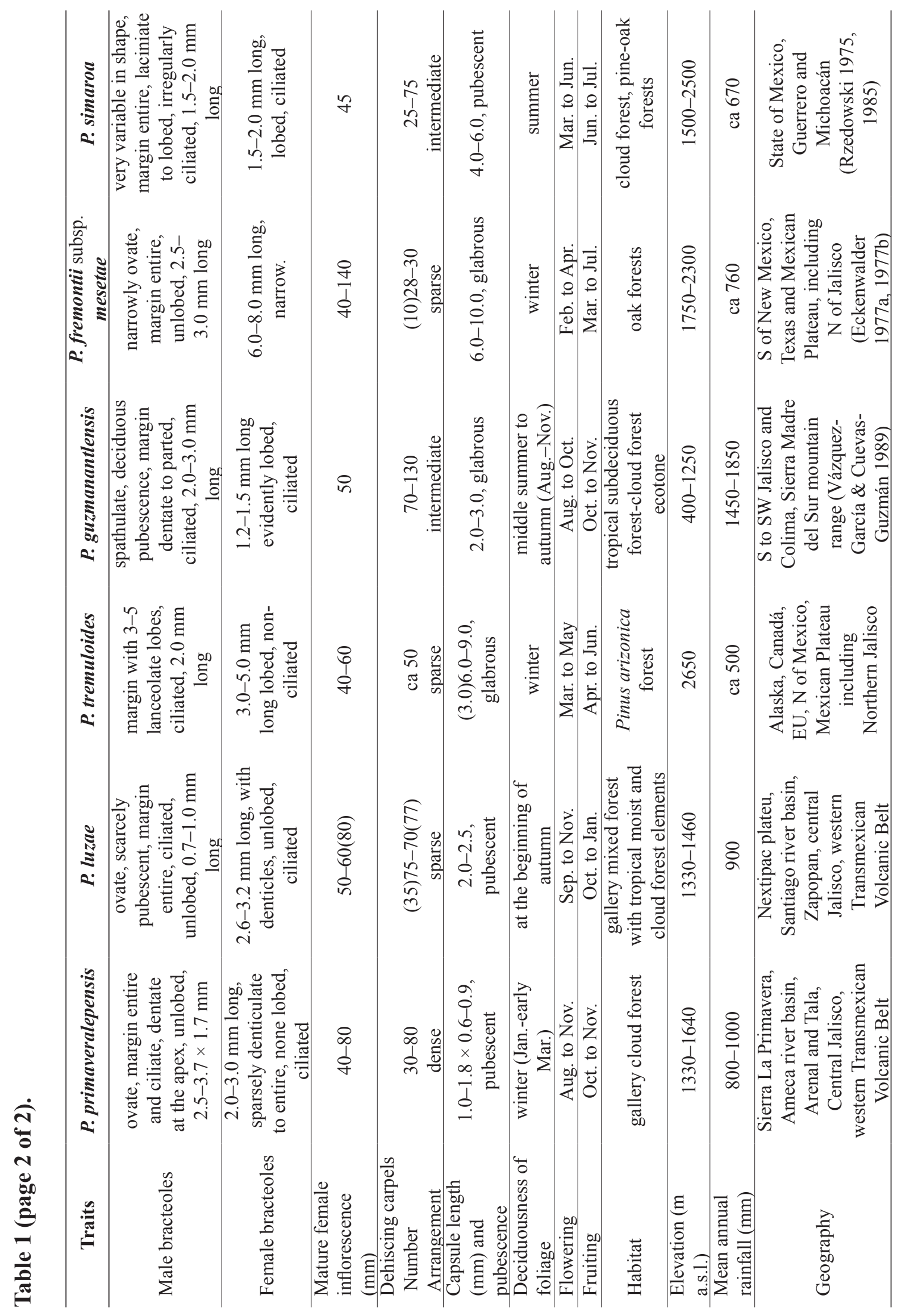




\title{
Results
}

\author{
Class Magnoliopsida Brongn. \\ Order Malpighiales Juss. ex Bercht. \& J.Presl \\ Family Salicaceae Mirb. \\ Genus Populus L. \\ Section Populus \\ Subsection Tomentosae Hart.
}

Populus primaveralepensis A.Vázquez, Muñiz-Castro \& Zuno sp. nov. urn:lsid:ipni.org:names:77194127-1

Figs $1-4$

\section{Differential diagnosis}

Populus primaveralepensis sp. nov. is morphologically close to $P$. luziarum, but it differs from the latter in possessing various qualitative and quantitative characters, such as having taller trees with nonsoboliferous habit, branching angle of $\mathrm{ca} 45^{\circ}$ with white and ringed bark, and leaves with higher blade to petiole ratio (large leaves with petioles $2.9-3.9$ vs $5.4-6 \mathrm{~cm}$ long, leaf blades frequently elliptic or ovate to widely ovate vs widely ovate to ovate-deltoid, $17-18.5 \mathrm{vs} 15.5-16 \mathrm{~cm}$ long, inflorescences dense vs sparse, and shorter capsules, $1.0-1.8$ vs $2.0-2.5 \mathrm{~mm}$ (Table 1).

\section{Type material}

\section{Holotype}

MEXICO • fr; Jalisco, Tala, along Río La Lobera, Llano Grande, Reserva de La Biosfera Bosque La Primavera; $20.6^{\circ}$ N, $103.6^{\circ} \mathrm{W} ; 1604$ m a.s.1.; 4 Mar. 2013; J. Antonio Vázquez-García, Padilla-Lepe, and Zuno-Delgadillo 10005 leg.; montane cloud forest relict; IBUG.

\author{
Isotypes \\ MEXICO • Same data as for the holotype; K, MEXU, MO, ZEA.
}

\section{Etymology}

The epithet honors the collective conservation accomplishments at Bosque La Primavera for its twelfth anniversary as a MaB-UNESCO Biosphere Reserve as well as the biologist Jesús Padilla Lepe, a young and enthusiastic botanical explorer graduated from the Universidad de Guadalajara who discovered the species.

\section{Other material examined}

MEXICO - Jalisco • $~$ fl buds; Municipio Arenal, Bosque La Primavera, $1.5 \mathrm{~km}$ S of Fraccionamiento El Roble; 2041'48.00" N, 10337'49.71" W; 1330 m a.s.1.; 25 Oct. 2009; M. Harker et al. 4045 leg.; IBUG • st; Municipio Tala, Bosque La Primavera, Llano Grande; 20³9'27" N, 103³7'39" W; 1604 m a.s.1.; 8 Feb. 2012; Padilla-Lepe and Zuno-Delgadillo s.n. leg.; IBUG • $\bigcirc$ fl; Tala, Arroyo La Lobera; $20^{\circ} 39^{\prime} 27.5^{\prime \prime} \mathrm{N}, 103^{\circ} 37^{\prime} 42.2^{\prime \prime} \mathrm{W} ; 1640$ m a.s.1.; 5 Nov. 2017; J. Padilla-Lepe, O. Ibarrarán-Madrigal, and J.J. Padilla-García 252a leg.; IBUG • $q$ fl, fr; same collection data as for preceding, J. PadillaLepe, O. Ibarrarán-Madrigal, and J.J. Padilla-García 252b leg.; IBUG • đ fl; Acequia, in the SE margin of the town of Tala, intersection at El Álamo, $1 \mathrm{~km}$ before the Higher Technological Institute of Tala; 20³8'33.56" N, 10341'52.18" W; 1332 m a.s.1.; 18 Aug. 2013; Vázquez-García et al. 10106b leg.; IBUG • + fl, fr; same collection data as for preceding; Vázquez-García et al. 10106c leg.; IBUG • ${ }^{\top}$; same collection data as for preceding; 2 Oct. 2017; Vázquez-García and Padilla-Lepe 10150 leg.; IBUG • 9 fl, fr; same collection data as for preceding; Vázquez-García and Padilla-Lepe 10151 leg.; IBUG • ${ }^{1} \mathrm{fl}$; Municipio de Tala, Arroyo La Lobera $3.5 \mathrm{~km}$ E del Macrolibramiento; 20³9'18.64" N, 


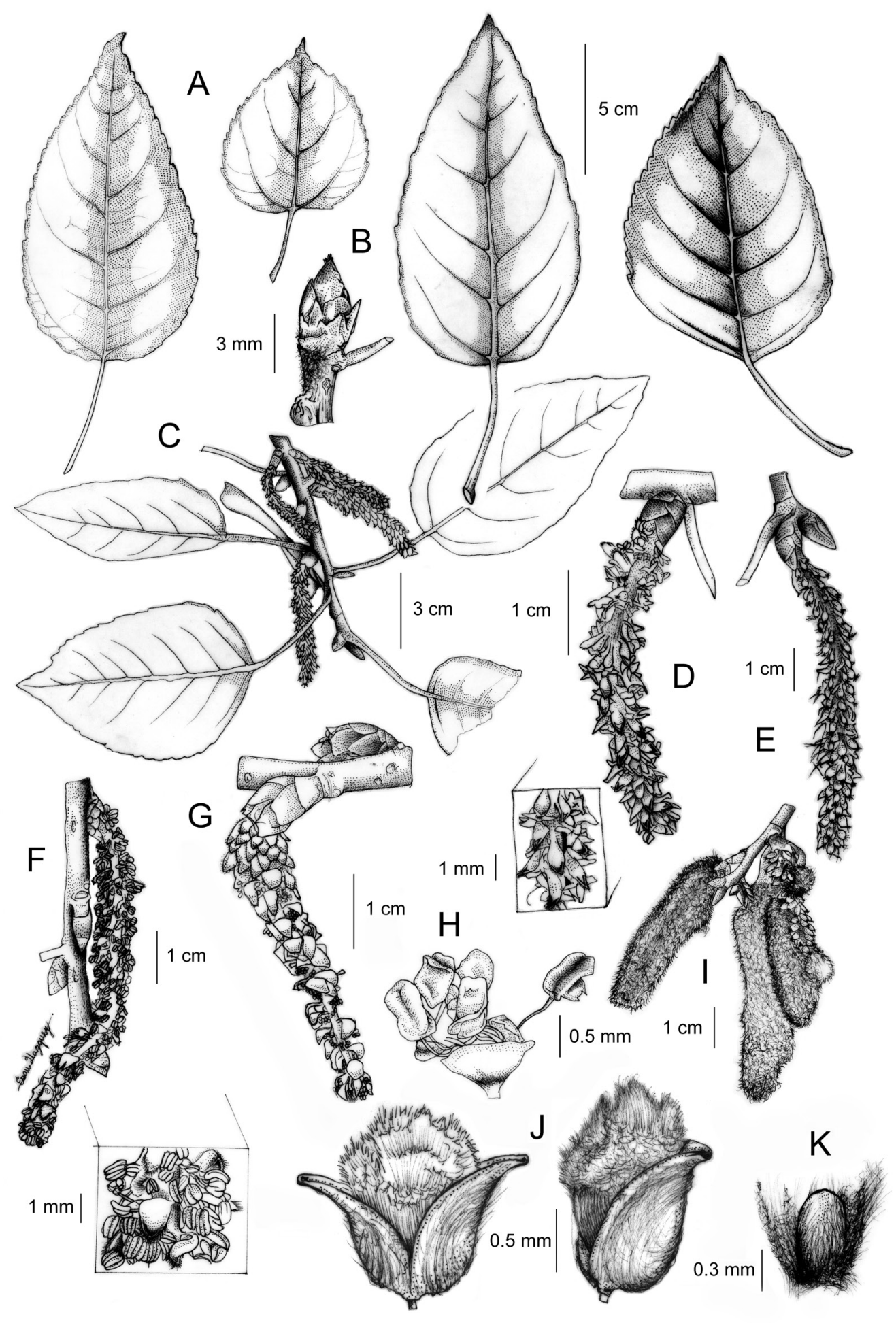

Fig. 1. Populus primaveralepensis A.Vázquez, Muñiz-Castro \& Zuno sp. nov. A-E, I-K. VázquezGarcía et al. 10106c leg., IBUG. F-H. Vázquez-García et al. 10106b leg., IBUG. A. Variability of leaves. B. Leaf bud. C. Branch with female inflorescence. D-E. Early and late state of inflorescence. F-G. Late and early male inflorescence. H. Male flower. I. Infrutescence with pappus. J. Capsule complete and in half, with pappus. K. Developing gynoecium. Illustrations: E. E. Vázquez-Verdejo. 


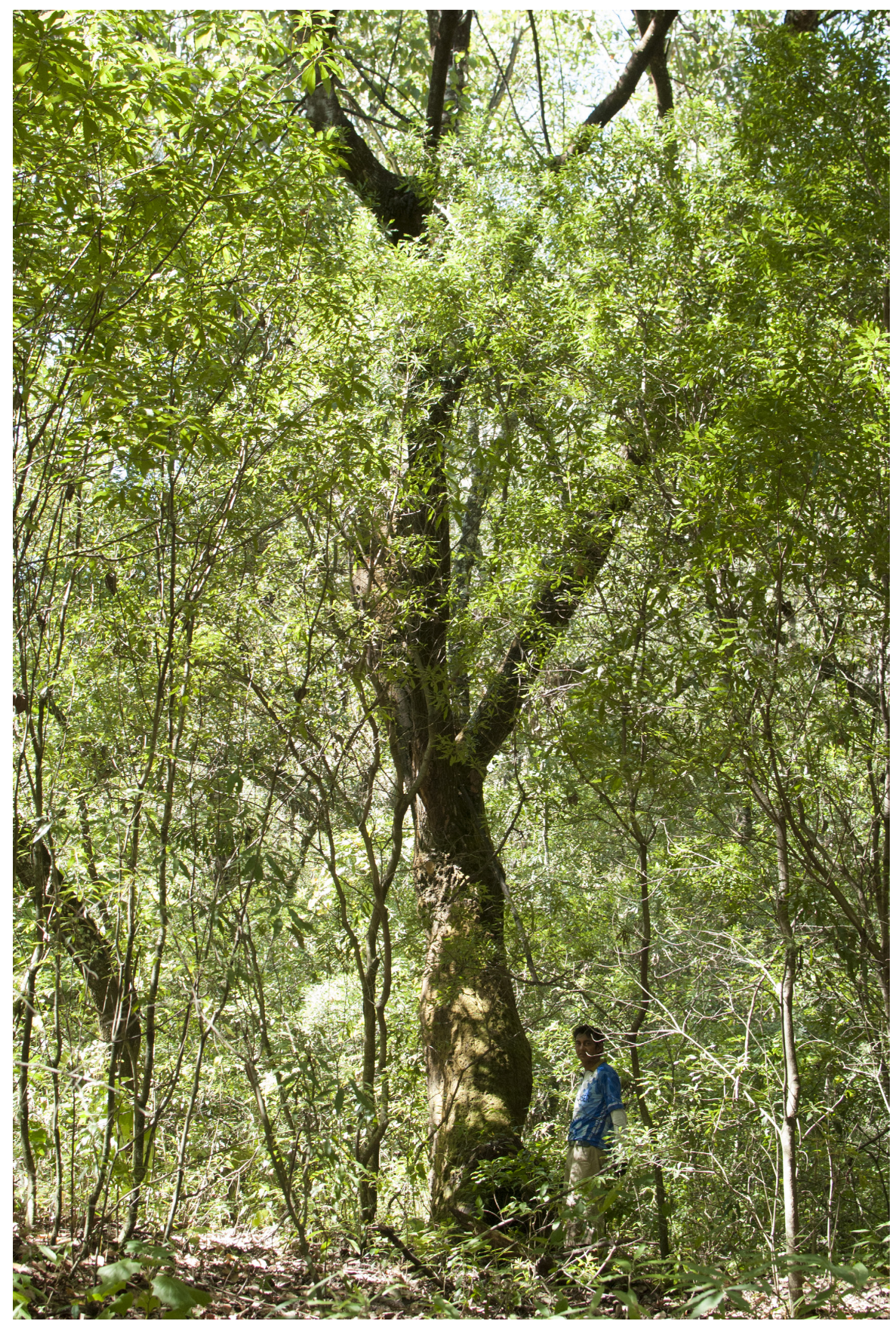

Fig. 2. Populus primaveralepensis A.Vázquez, Muñiz-Castro \& Zuno sp. nov. Tree showing its habit and bark. J. Padilla Lepe, standing next to the tree; photograph: O. Ibarrarán. 


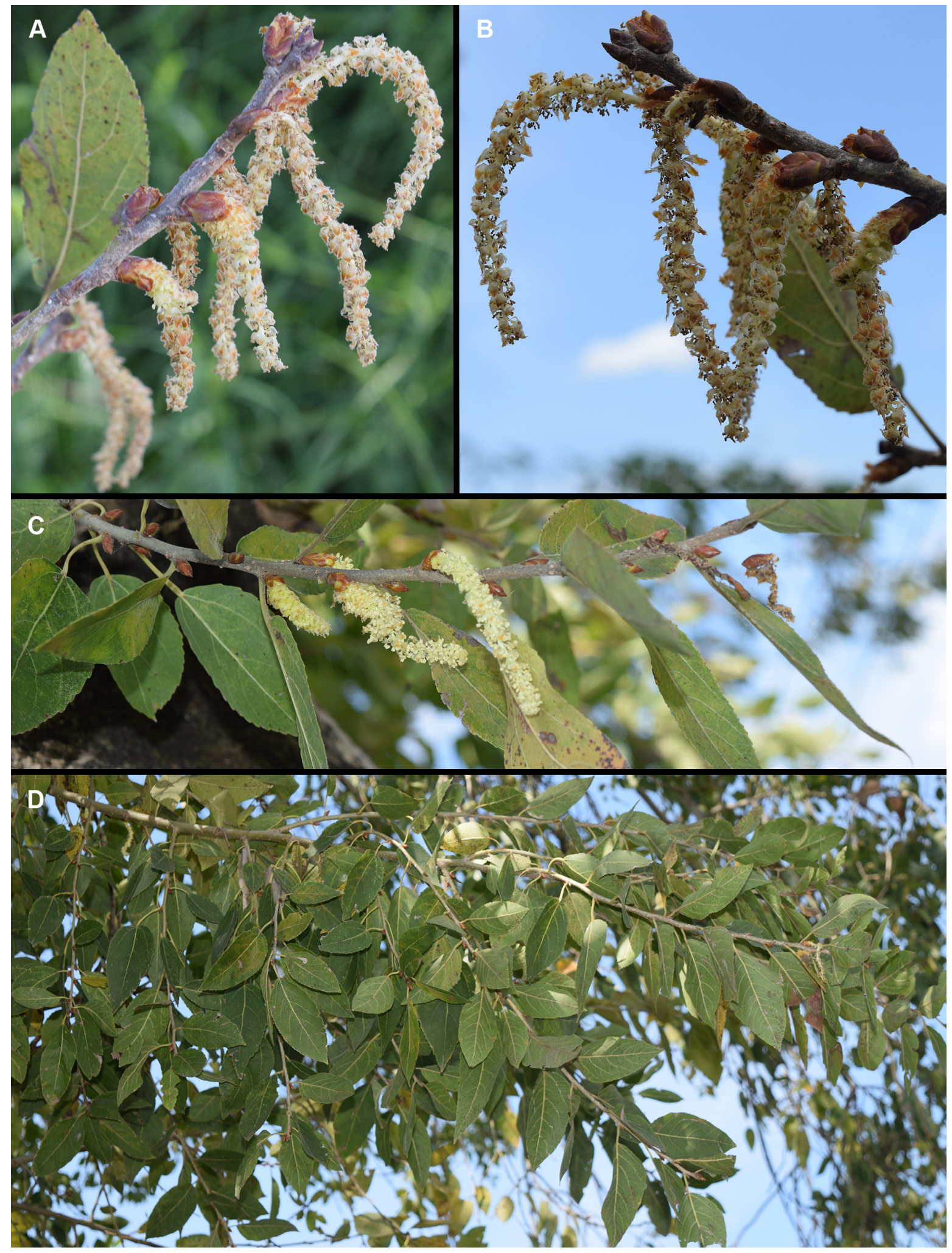

Fig. 3. Populus primaveralepensis A.Vázquez, Muñiz-Castro \& Zuno sp. nov., male individual, Vázquez-García et al. 10106b leg., IBUG. A-B. Two views of same branch with inflorescence past anthesis. C. Inflorescence at anthesis. D. Branch showing leaf variability and venation. Photographs: A. Vázquez. 


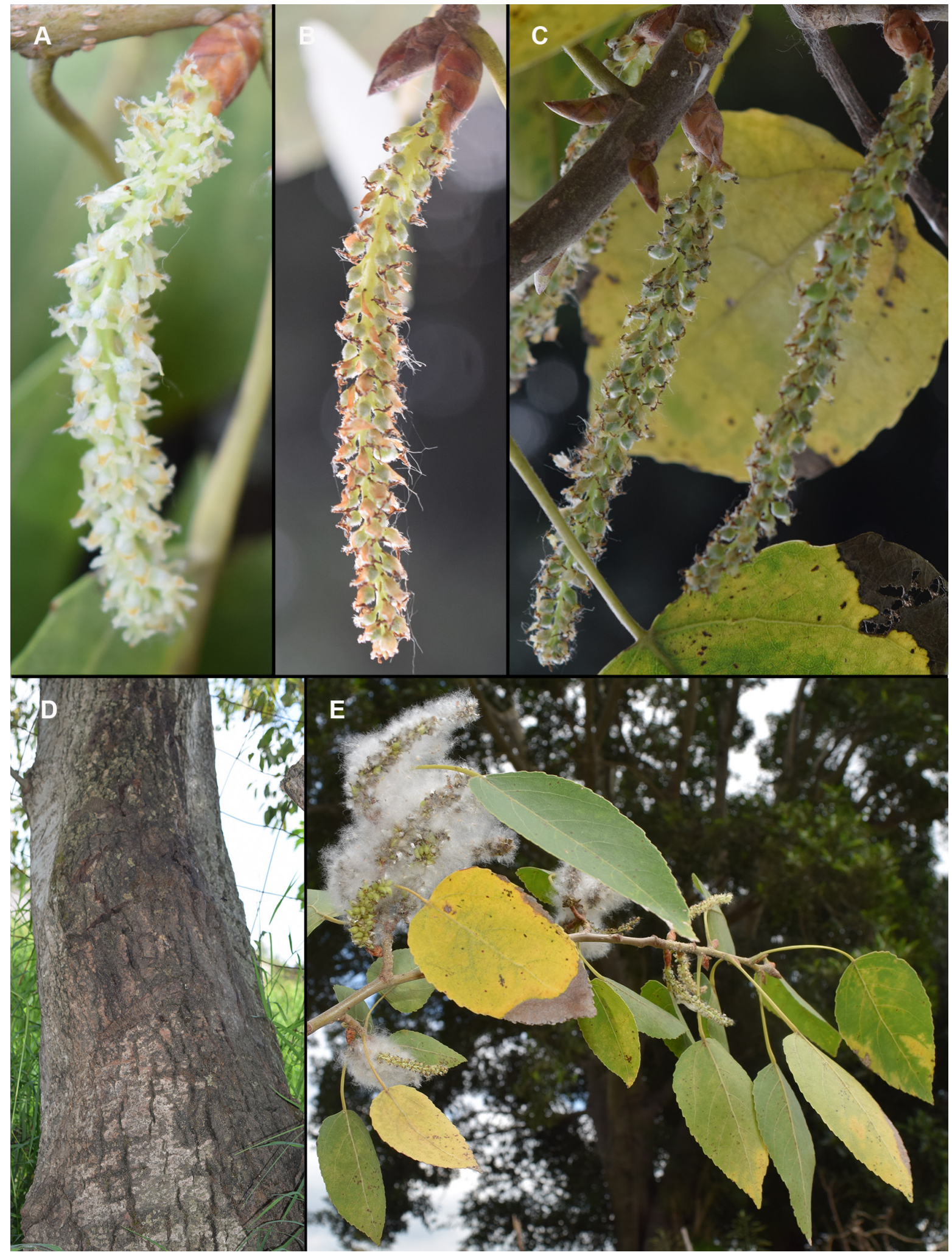

Fig. 4. Populus primaveralepensis A.Vázquez, Muñiz-Castro \& Zuno sp. nov., female individual, Vázquez-García et al. 10106c leg., IBUG. A. Inflorescence at anthesis. B. Inflorescence past anthesis. C. Developing infrutescence. D. Trunk. E. Branch with leaves and dehiscing capsules, showing the whitish pappus of seeds. Photographs: A. Vázquez. 
103³8'56.54" W; 1427 m a.s.1.; 31 Oct. 2017; H. Luquín-Sánchez and G. Nieves-Hernández s.n. leg.; IBUG • + fl, fr; same collection data as for preceding; $20^{\circ} 39^{\prime} 17.28^{\prime \prime} \mathrm{N}, 103^{\circ} 39^{\prime} 7.25^{\prime \prime} \mathrm{W} ; 1439 \mathrm{~m}$ a.s.l.; H. Luquín-Sánchez and G. Nieves-Hernández s.n. leg.; IBUG.

\section{Description}

Trees 5-30 m tall; trunk $0.3-1.2 \mathrm{~m}$ in diameter at breast height, branched or single stemmed; spreading exclusively by seeds (non-soboliferous); bark smooth and whitish at sapling stage, and upper branches occasionally becoming shallowly furrowed and never tessellated. Petioles $2.0-4.2(5.4) \mathrm{cm}$ long, flattened near the leaf union, densely pubescent. Leaf blades (7.0)9.3-18.5 × (4.5)7-10.2-(14.3) cm, elliptic to ovate to widely ovate, rounded to subcordate at the base and acute at the apex, abaxially and densely pubescent throughout. Bud of the male inflorescence 5-7 $\times 2-3 \mathrm{~mm}$, bright reddish brown, glabrescent, with 6 scales. Male ament 10-70 $\times 10-25 \mathrm{~mm}$, cylindrical, pendulous and curved, with densely arranged flowers; rachis 1.0-1.5 mm thick, creamy to white, brown when it dries, glabrous; pedicels $0.5-1.5 \mathrm{~mm}$ long, greenish; bracteoles 2.5-3.7 $\times 1.7 \mathrm{~mm}$, ovate, with margin entire and ciliate, unlobed, dentate at the apex, reddish brown. Staminate flowers 48-50, 1.5-2.2 mm long, pedicellate; pedicels $0.3-0.5 \mathrm{~mm}$ long; floral disc 1.0-1.2 in diameter, meniscoid, shallow cup, shaped to patelliform, oblique, creamy, brown yellowish when it dries; stamens 6-12, free; filaments $0.5-0.7 \mathrm{~mm}$ long, glabrous; anthers $0.6-1.5 \times$ $0.5-0.8 \mathrm{~mm}$, pale yellow, basifix and oblong, longitudinal dehiscence, with tecae $0.6-1.5 \times 0.2-0.3 \mathrm{~mm}$. Bud of the female inflorescence 6-15 $\times 3-5 \mathrm{~mm}$; scales 6-7, 1-5 $\times 2-6 \mathrm{~mm}$, brown reddish, glabrescent. Female ament $40-80 \mathrm{~mm}$, cylindrical, dense; rachis $1.0-1.5 \mathrm{~mm}$ width; pedicels $0.5-1.5 \mathrm{~mm}$ long, greenish-yellow color, brown when it dries, sparsely ciliate; bracteoles 2-3 $\times 1-2 \mathrm{~mm}$, narrowly ovate to elliptic to broadly spathulate, with margin sparsely denticulate to entire, non-lobed, ciliate, caducous, greenish yellow at anthesis, brown-reddish when it dries. Pistillate flowers 30-80, 1.0-1.5 mm long, glabrous; pedicel $0.5-1.0 \mathrm{~mm}$; floral disc $1.2-1.8 \mathrm{~mm}$ in diameter, ciathiform, scarcely ciliated; ovary inferior, pisiform, pubescent to glabrescent; styles $0.5-2.0 \mathrm{~mm}$ long, each branched into curved stigmas. Infrutescence 20-80 $\times 10-20 \mathrm{~mm}$; rachis $1.0-1.5 \mathrm{~mm}$ thick, brown and glabrate; peduncle 1.0-1.2 mm long; brown and glabrate; bracteoles 3.5-4.0 $\times 1.2-1.8 \mathrm{~mm}$, narrowly ovate to elliptic to broadly spathulate, margin sparsely denticulate to entire, non-lobed, ciliate, caducous, greenish yellow at anthesis, brown-reddish when it dries; capsules 30-80, 1.0-1.8 $\times 0.6-0.9 \mathrm{~mm}$, bivalved, closed, narrowly ovoid, pubescence translucent; seeds $1-3$ per capsule, $0.3-0.7 \times 0.2-0.4 \mathrm{~mm}$, creamy yellowish or reddish brown; pappus 4-6 mm long, yellowish brown or white.

\section{Distribution, habitat and phenology}

Western Mexico: State of Jalisco, Bosque La Primavera Biosphere Reserve, along the tributaries of Río La Lobera and Río Caliente, in the municipalities of Tala and Arenal, respectively (Fig. 5).

The relict gallery cloud forest includes Clethra rosei Britton (Clethraceae Klotzsch), Ficus insipida Willd. (Moraceae Gaudich.), Ilex dugesii Fernald (Aquifoliaceae Bercht. \& J.Presl), Morella cerifera (L.) Small (Myricaceae Rich. ex Kunth), Persea hintonii C.K. Allen (Lauraceae Juss.), Prunus serotina subsp. capuli (Cav.) McVaugh (Rosaceae Juss.), Quercus magnoliffolia Née and Quercus gentryi C.H.Muller (Fagaceae Dumort.), and Salix taxifolia Kunth (Salicaceae Mirb.) (Table 1). The flowering occurs from August to November, the fruiting from October to November, and deciduous foliage can be observed during winter, from January to early March.

\section{Taxonomic remarks}

Because of its bifacial leaves, broad ciliate bracts; persistent, entire and oblique disk, two carpels, and 4-6 seeds, P. primaveralepensis sp. nov. falls within P. sect. Populus, the most speciose section of the genus (13 species); it belongs to $P$. subsect. Tomentosae, a subsection consisting of white poplars with abaxially pubescent leaves (Eckenwalder 1977a, 1977b). Populus primaveralepensis sp. nov. is 

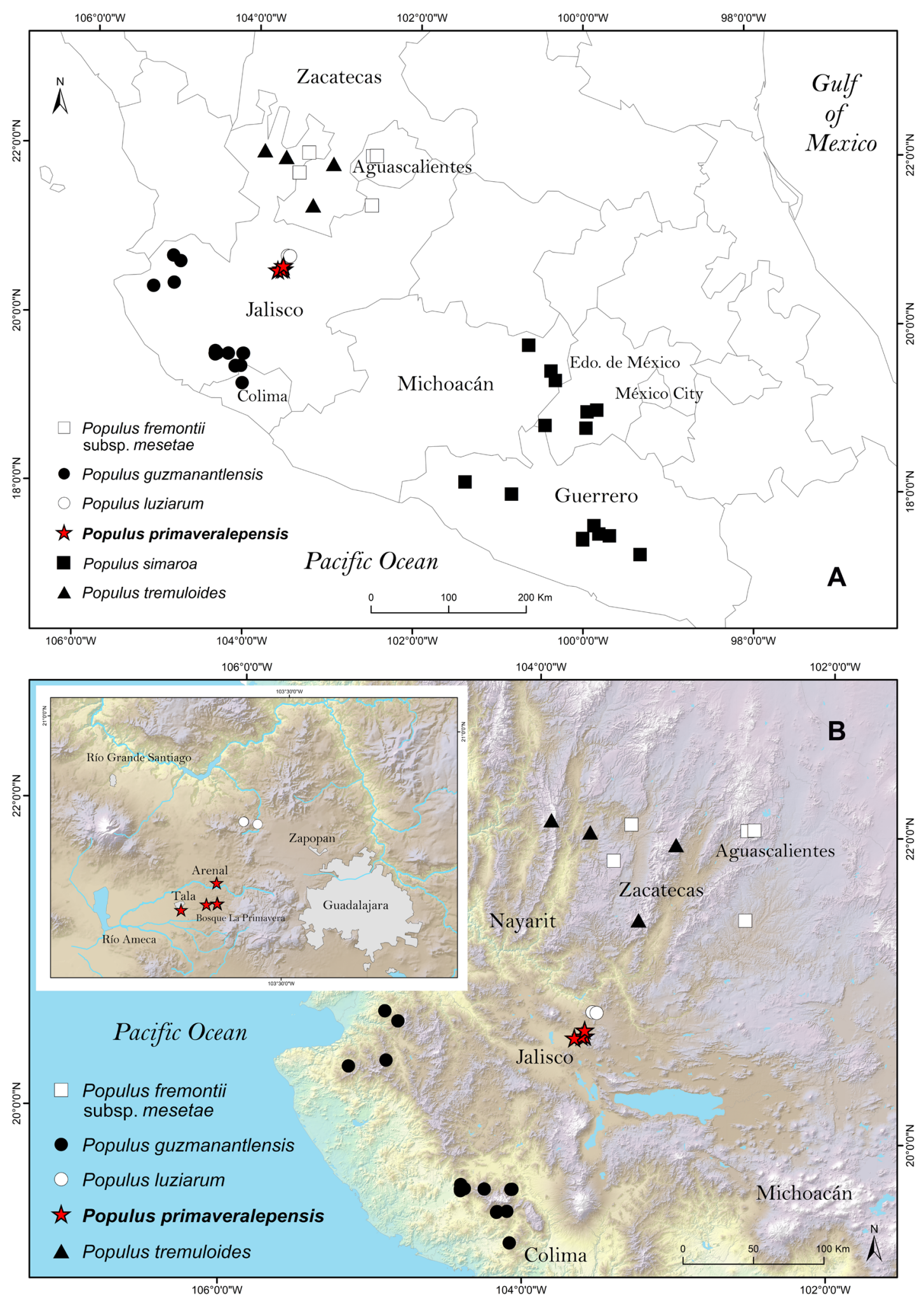

Fig. 5. Maps. A. Distribution of P. primaveralepensis A.Vázquez, Muñiz-Castro \& Zuno sp. nov. and related species of Populus L. in western Mexico. B. Distribution of the species of Populus in Jalisco with a close up for $P$. luziarum A.Vázquez, Muñiz-Castro \& Padilla-Lepe and P. primaveralepensis sp. nov. 
morphologically close to $P$. luziarum in having abaxially tomentose leaves and buds; however, it differs from the latter in having a taller habit (25-30 vs 15-20 m), a different type of spread (exclusively by seeds vs both by seeds and by means of root-borne sucker shoots), branches white and ringed vs brown and not ringed, branching angle (usually ca $45 \mathrm{vs}>75^{\circ}$ ), longer large-sized leaves with shorter petioles, elliptic to ovate to widely ovate vs widely ovate to ovate-deltoid, rounded to subcordate at the base vs obtuse to rounded to subcordate, and acute at the apex vs rounded, acute to shortly apiculate (Table 1). Additionally, $P$. primaveralepensis sp. nov. differs from P. luziarum in terms of its phenology, losing leaves during winter vs autumn.

\section{Ethnobotany}

The species is locally known as "álamo". There is no available information on the use of the species in Jalisco; however, sometimes it is kept as a shade tree for cows. Like other species in the genus Populus, P. primaveralepensis sp. nov. is a potential source of cellulose fibers, and can be used as an ornamental tree, or for restoration of watersheds in central Jalisco.

\section{Conservation status}

Populus primaveralepensis sp. nov. consists of four small and restricted subpopulations: (1) a single tree in a water spring of a tributary of Río Caliente, Arenal, Bosque La Primavera $\left(20^{\circ} 41^{\prime} 48.00^{\prime \prime} \mathrm{N}\right.$, $\left.103^{\circ} 37^{\prime} 49.71^{\prime \prime} \mathrm{W}\right) ;(2)$ a second and largest population (ca 100 trees), located at Llano Grande, Tala, along the Lobera River in Bosque La Primavera $\left(20^{\circ} 39^{\prime} 27.5^{\prime \prime} \mathrm{N}, 103^{\circ} 37^{\prime} 42.2^{\prime \prime} \mathrm{W}\right)$; (3) eight trees including some old-growth forms in Tala, along the road to the Instituto Tecnológico Superior de Tala $\left(20^{\circ} 38^{\prime} 33.56^{\prime \prime} \mathrm{N}, 103^{\circ} 41^{\prime} 52.18^{\prime \prime} \mathrm{W}\right)$, the older trees, ca $1 \mathrm{~m}$ in diameter, are ca 80 years old; (4) two additional trees, nearly $2 \mathrm{~km}$ east of the "Macrolibramiento" highway of the Guadalajara metropolis, along Río La Lobera $\left(20^{\circ} 39^{\prime} 18.64^{\prime \prime} \mathrm{N}, 103^{\circ} 38^{\prime} 56.54^{\prime \prime} \mathrm{W}\right.$, male tree; $20^{\circ} 39^{\prime} 17.28^{\prime \prime} \mathrm{N}, 103^{\circ} 39^{\prime} 7.25^{\prime \prime} \mathrm{W}$, female tree).

The known Extent of Occurrence (EOO) of $P$. primaveralepensis sp. nov. is ca $97.88 \mathrm{~km}^{2}$, but from this area, only an Area of Occupancy (AOO) of ca $48.29 \mathrm{~km}^{2}$ is represented by its habitat (relict gallery cloud forests in humid ravines); the rest is occupied by human settlements (Tala city and La Primavera town), country roads, highways, agriculture, and pasturelands, even inside the BLPBR. Hence, according with IUCN Red List criteria B1ab(iii) (IUCN 2012), P. primaveralepensis sp. nov. should be categorized as Critically Endangered, an addition to the flora of conservation concern at BLPBR (Table 2), because it has an EOO $<100 \mathrm{~km}^{2}$, very small and restricted subpopulations which are severely fragmented; there are less than 120 individuals known, and there is a continuing observed and projected decline in the area and quality of its habitat (relict gallery cloud forest).

Populus primaveralepensis sp. nov. is extremely rare, thus it should be protected immediately. It is important to disseminate this case and alert the general public that the fragmentation of habitats (mainly road expansion) represents a great threat for these fragile relict ecosystems, which have harboured numerous species for over one hundred millennia (Mahood 1980).

\section{Discussion}

\section{Conservation status}

Populus primaveralepensis sp. nov. and $P$. luziarum belong to the $P$. subsect. Tomentosae and are likely closely related phylogenetically. Based on cpDNA sequences, it has been confirmed that $P$. sect. Populus represents a monophyletic group, although the phylogenetic relationships within the section are still uncertain (Wang et al. 2015; Zhang et al. 2017). This section has a relatively young evolutionary history, and because of fossil records, and morphological and molecular phylogenetic analyses (Eckenwalder 1996; Wang et al. 2014, 2015), it is inferred that this group originated from the rapid radiation of 


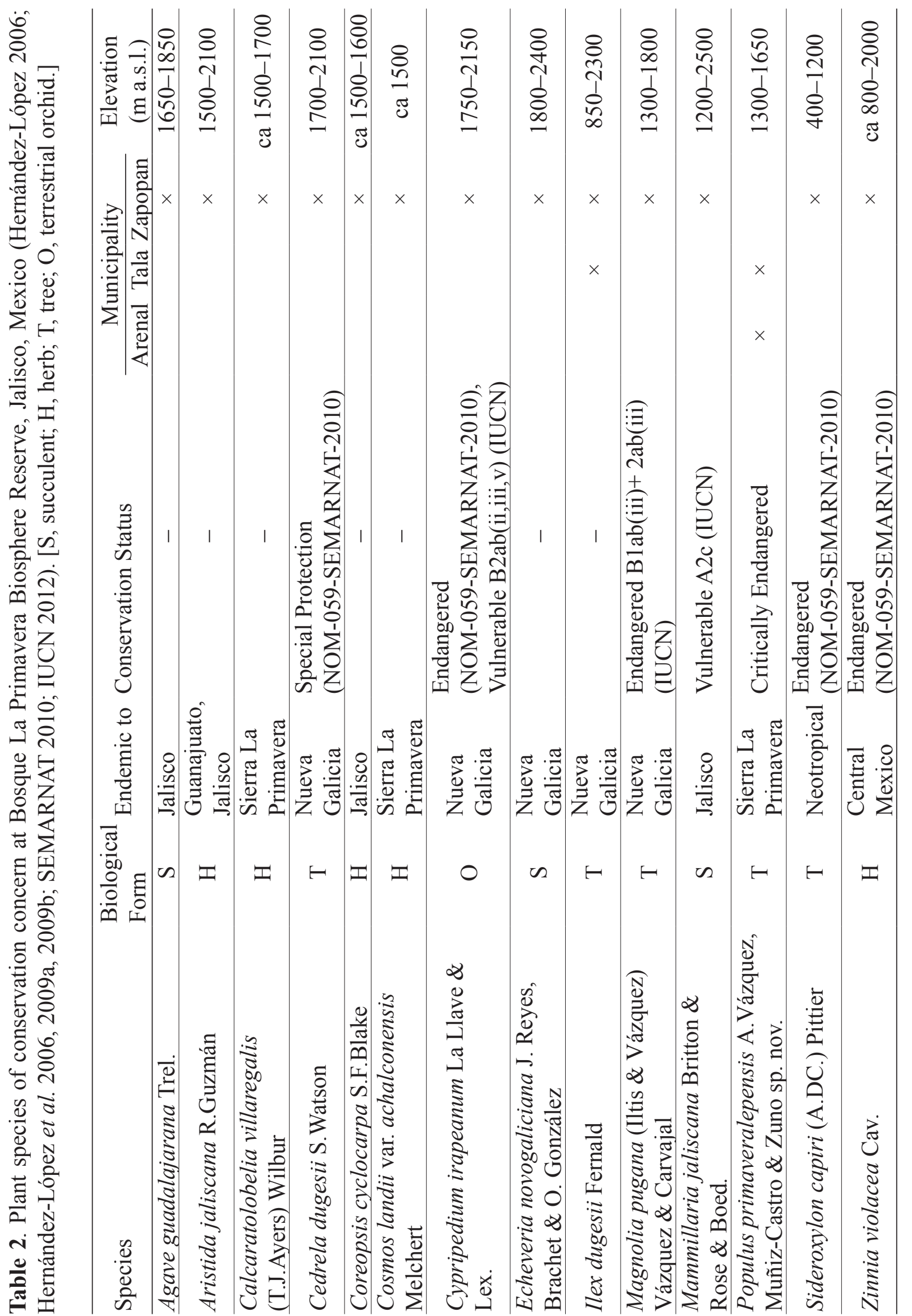


an ancestral member of $P$. sect. Leucoides Spach. The relative recent morphological and evolutionary divergence is presented by the similarities exhibited by $P$. luziarum and P. primaveralepensis sp. nov., which could have migrated from a Pleistocene refuge in the Sierra Madre Occidental to the geologically recent Sierra La Primavera volcanic complex (western Transmexican Neovolcanic Belt), which was formed by several eruptions that happened between 120000 and 20000 years ago (Mahood 1980). Both species are linked to ravines and permanent streams, and have certainly played an important role in the maintenance and continuity of these ecosystems for at least 120000 years. Even though the geographical ranges of the two species are only $13.5 \mathrm{~km}$ apart, they occur in different basins (Río Ameca and Río Santiago, respectively), exhibiting distinct geomorphological features, and atmospheric and climatic conditions (SEMADES 2006).

\section{Floristic relevance}

The riparian communities of $P$. primaveralepensis sp. nov. and $P$. luziarum do not share any tree species (100\% dissimilar). Hence, according with their current floristic composition (Table 1), it is evident that the two areas represent two distinct biogeographical histories, with no recent exchange between them, which deserve more attention; they will provide a great opportunity to study the incipient evolutionary history of various floristic elements that have presumably migrated to the La Primavera Forest from the older Sierra Madre Occidental.

Mexico, now with eleven species of Populus, represents one third of the worldwide richness of this genus (POWO 2018), and is the richest in the continent followed by USA (eight species) and Canada (five species). Jalisco, with a 45\% (five species) of the Mexican species of Populus, now matches Chihuahua in terms of absolute richness of species of Populus, even though the latter area is nearly three times larger in area $\left(247460 \mathrm{vs} 79080 \mathrm{~km}^{2}\right)$.

Populus primaveralepensis sp. nov. is now the first species categorized as Critically Endangered (CR) within BLPBR, out of the 14 species of conservation concern in this protected area (Table 2), a reserve with more than 1000 species of vascular plants.

\section{Acknowledgments}

We thank the University of Guadalajara-CUCBA, PRODEP-SEP, and SNI-CONACyT, Mexico, for their financial support. We acknowledge curators of the herbaria IBUG and ZEA for their collaboration, Héctor Luquín Sánchez for adding an additional location of the species and Esau Vázquez Verdejo for the illustration. We appreciate the contribution of all reviewers and editors of this manuscript, including Dra. Irina Belyaeva. We thank Dr. Servando Carvajal for his guidance with Latin.

\section{References}

Dickmann D.I. \& Kuzovkina J. 2014. Poplars and willows of the world, with emphasis on silviculturally important species. In: Isebrands J.G. \& Richardson J. (eds.) Poplars and Willows: Trees for Society and the Environment: 88-91. CAB International \& FAO, Rome. https://doi.org/10.1079/9781780641089.0008

Eckenwalder J.E. 1977a. North American cottonwoods (Populus, Salicaceae) of sect.s Abaso and Aigeiros. Journal of the Arnold Arboretum 58: 193-208. https://doi.org/10.5962/bhl.part.29239

Eckenwalder J.E. 1977b. Systematics of Populus L. (Salicaceae) in southwestern North America with special reference to sect. Aigeiros Duby. PhD thesis, University of California, Berkeley.

Eckenwalder J.E. 1996. Systematics and evolution of Populus. In: Stettler R.F., Bradshaw Jr. H.D, Heilman P.E. \& Hinckley T.M. (eds) Biology of Populus and its Implications for Management and Conservation: 7-32. NRC Research Press, Ottawa. 
Eckenwalder J.E. 2010. Populus. In: Flora of North America Editorial Committee (eds) Flora of North America North of Mexico: 5-22. Oxford University Press, New York and Oxford.

Hernández-López L. 2006. Especies de plantas con problemas de conservación en el en Bosque La Primavera, Jalisco, México. In: Santiago Pérez A.L. (ed.) I Foro de Investigación y Conservación del Bosque La Primavera, Sep. 22-23, 2005: 48-49. Zapopan, Jalisco.

Hernández-López L., González-Hernández C.G., Harker M. \& Ramírez-Delgadillo R. 2006. Datos preliminares sobre la distribución y el estado de conservación de tres especies en el Bosque La Primavera, Zapopan, Jalisco. In: Carvajal S. (ed.) Avances en la Investigación Cientifica en el Centro Universitario de Ciencias Biológicas y Agropecuarias: 348-351. CUCBA, Zapopan.

Hernández-López L., Harker M. \& Ramírez-Delgadillo R. 2009a. Nuevas localidades de Lobelia villaregalis (Campanulaceae: Lobelioideae), especie endémica de Jalisco. In: Carvajal S. \& PimientaBarrios E. (eds) 2008 Avances en la Investigación en el CUCBA, XIX Semana Nacional de La Investigación Cientifica: 213-215. CUCBA, Zapopan.

Hernández-López L., Ramírez-Delgadillo R. \& Harker M. 2009b. Fitogeografía de tres especies de plantas sujetas a protección especial y amenazadas en el Bosque La Primavera, Jalisco. In: VillavicencioGarcía R., Santiago-Pérez A.L., Gallegos-Rodríguez A., Hernández-Álvarez E., Hernández López L. \& Rodríguez-Alcántar O. (eds) II Foro de Investigación y Conservación del Bosque La Primavera: Memorias. March 5-6, 2009: 163-172. Zapopan, Jalisco.

IPNI 2018. International Plant Names Index. Available from: http://www.ipni.org [accessed 7 Apr. 2018].

IUCN 2012. Guidelines for Application of IUCN Red List Criteria at Regional and National Levels: Version 4.0. Gland, Switzerland and Cambridge.

Mahood G. A. 1980. Geological evolution of a Pleistocene rhyolitic center-Sierra la Primavera, Jalisco, Mexico. Journal of Volcanology and Geothermal Research 8: 199-230. https://doi.org/10.1016/0377-0273(80)90105-5

Martínez-González R.E. \& González-Villarreal L.M. 2002. La familia Salicaceae (Populus) en el estado de Jalisco, México. Instituto de Botánica, Universidad de Guadalajara, Guadalajara.

Martínez-González R.E. \& González-Villarreal L.M. 2005. Taxonomía y biogeografía del género Populus, (Salicaceae) en México. Universidad de Guadalajara, Guadalajara.

Michaux A. 1803. Flora Boreali-Americana. Vol. 2. Levrault, Paris and Strasbourg.

POWO 2018. Plants of the World Online. Available from: http://www.plantsoftheworldonline.org [accessed 10 Apr. 2018].

Radford A.E., Dickison W.C., Massey J.R. \& Bell C.R. 1974. Vascular Plant Systematics. Harper and Row, New York.

Rzedowski J. 1975. Tres dicotiledóneas mexicanas nuevas de posible interés ornamental. Boletín de la Sociedad Botánica de México 35: 37-43.

Rzedowski J. 1985. Análisis de la distribución geográfica de las especies mexicanas del género Populus (Salicaceae). Compte rendu Somaire des Séances de la Société de Biogéographie 60: 141-150.

SEMADES 2006. Diagnóstico de los Subsistemas. Subsistema Natural - Medio Físico. Clima. Cuencas atmosféricas para el Estado de Jalisco. Geomática. Informe Final del Proyecto de Ordenamiento Ecológico Territorial del Estado de Jalisco, México. Available from http://siga.jalisco.gob.mx/moet [accesssed 22 Sep. 2018]. 
SEMARNAT 2010. Norma Oficial Mexicana NOM-059-SEMARNAT-2010, Protección ambientalEspecies nativas de México de flora y fauna silvestres-Categorías de riesgo y especificaciones para su inclusión, exclusión o cambio-Lista de especies en riesgo. Diario Oficial de la Federación (30 Dec. 2010) 2: 1-77.

Thiers B. 2017. Index Herbariorum: A Global Directory of Public Herbaria and Associated Staff. New York Botanical Garden's Virtual Herbarium. Available from: http://sweetgum.nybg.org/science/ih [accessed 10 Nov. 2017].

Vázquez-García J.A. \& Cuevas-Guzmán R. 1989. Una nueva especie tropical de Populus (Salicaceae) de la Sierra de Manantlán, Jalisco, México. Acta Botánica Mexicana 8: 39-45. https://doi.org/10.21829/abm8.1989.586

Vázquez-García J.A., Muñiz-Castro M.A., Padilla-Lepe J., Pulido-Ávila M.G., Nieves-Hernández G. \& Martínez-González R.E. 2017. Populus luzae [luziarum] (Salicaceae), a new species of white poplar endemic to the western Transmexican Volcanic Belt, in Zapopan, Jalisco, Mexico. Phytotaxa 328 (3): 243-256. https://doi.org/10.11646/phytotaxa.328.3.3

Wang Z., Du S., Dayanandan S., Wang D., Zeng Y. \& Zhang J. 2014. Phylogeny reconstruction and hybrid analysis of Populus (Salicaceae) based on nucleotide sequences of multiple single-copy nuclear genes and plastid fragments. PLOS ONE 9 (8): e103645. https://doi.org/10.1371/journal.pone.0103645

Wang D., Wang Z., Du S. \& Zhang J. 2015. Phylogeny of sect. Leuce (Populus, Salicaceae) inferred from 34 chloroplast DNA fragments. Biochemical Systematics and Ecology 63: 212-217. https://doi.org/10.1016/j.bse.2015.09.020

Zhang L., Shang C., Du F.K., Zhao F., Xiong B. \& Zhang Z. 2017. Chloroplast phylogenomic analyses maternal relationships among sections in the genus Populus. Biochemical Systematics and Ecology 70: 132-140. https://doi.org/10.1016/j.bse.2016.11.008

Manuscript received: 28 April 2018

Manuscript accepted: 30 November 2018

Published on: 14 February 2019

Topic editor: Frederik Leliaert, Ph.D.

Desk editor: Alejandro Quintanar

Printed versions of all papers are also deposited in the libraries of the institutes that are members of the EJT consortium: Muséum national d'Histoire naturelle, Paris, France; Meise Botanic Garden, Belgium; Royal Museum for Central Africa, Tervuren, Belgium; Royal Belgian Institute of Natural Sciences, Brussels, Belgium; Natural History Museum of Denmark, Copenhagen, Denmark; Naturalis Biodiversity Center, Leiden, the Netherlands; Museo Nacional de Ciencias Naturales-CSIC, Madrid, Spain; Real Jardín Botánico de Madrid CSIC, Madrid, Spain; Zoological Research Museum Alexander Koenig, Bonn, Germany. 